Financialisation in the European Periphery and the Sovereign Debt Crisis: The Portuguese Case

Ricardo Barradas Sérgio Lagoa

Emanuel Leão

Ricardo Paes Mamede

Dezembro de 2015

WP n. ${ }^{\circ} 2015 / 12$

DOCUMENTO DE TRABALHO

WORKING PAPER

DINAMIP'CET

CENTRO DE ESTUDOS SOBREA MUDANCA
SOCIOECONOMICA EO TERRITOBIO

ISCTE-IUL

FCT

Fundaçáo para a Ciência e a Tecnologia 
Financialisation in the European Periphery and the Sovereign Debt Crisis:

The Portuguese Case

\author{
Ricardo Barradas * \\ Sérgio Lagoa ** \\ Emanuel Leão $* * *$ \\ Ricardo Paes Mamede ****
}

WP n. ${ }^{\circ} 2015 / 12$

DOI: 10.15847/dinamiacet-iul.wp.2015.12

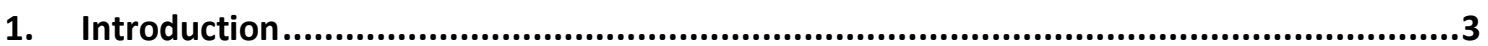

2. Financialisation and Its Consequences: A Reference to the Literature ........................4

3. The Change in the Regulatory Framework: Creating the Conditions for Financialisation .7

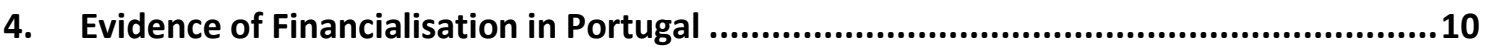

4.1 Indebtedness of the Private Non-Financial Sector and Growth of the Financial Sector ...........10

4.2 Financial Engagement of Non-Financial Corporations............................................................ 16

S.3 Sectorial Distribution of Credit across Industries ............................................................ 17

4.4 Broadening of Private Interests in the Economy, Taxes and Public Policy ............................. 18

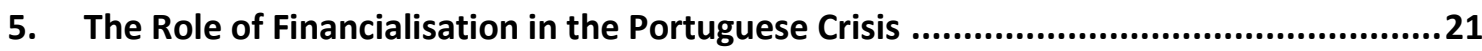

5.1 The Long-Run Development Pattern and the Turn of the Millennium: Structural Problems and

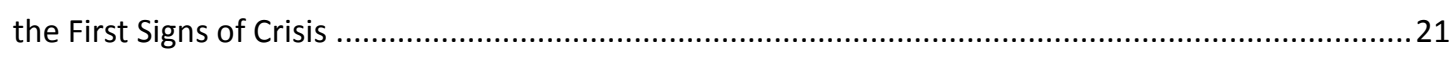

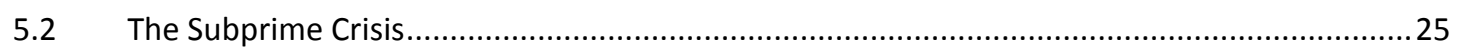

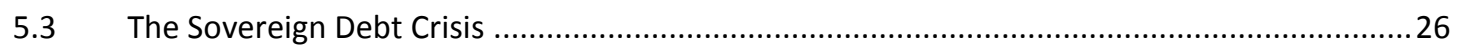

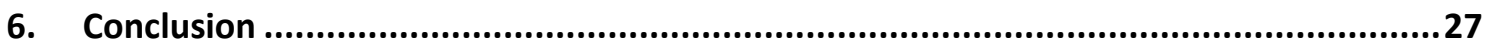

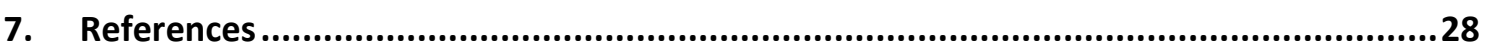

\footnotetext{
*Instituto Universitário de Lisboa (ISCTE-IUL), DINÂMIA-CET-IUL, Lisboa, Portugal. Higher School of Communication and Media Studies (Polytechnic Institute of Lisbon) Higher Institute of Accounting and Administration of Lisbon (Polytechnic Institute of Lisbon). rbarradas@escs.ipl.pt/rpbarradas@iscal.ipl.pt **Instituto Universitário de Lisboa (ISCTE-IUL), DINÂMIA-CET-IUL, Lisboa, Portugal. sergio.lagoa@iscte.pt ***Instituto Universitário de Lisboa (ISCTE-IUL), DINÂMIA-CET-IUL, Lisboa, Portugal.emanuel.leao@iscte.pt *****Instituto Universitário de Lisboa (ISCTE-IUL), DINÂMIA-CET-IUL, Lisboa, Portugal. ricardo.mamede@iscte.pt
} 


\title{
Financialisation in the European Periphery and the Sovereign Debt Crisis:
} The Portuguese Case ${ }^{1}$

\begin{abstract}
The financial sector has acquired great prominence in most developed economies. However, some authors argue that the growth of finance is at the root of the current financial and economic difficulties. This paper aims to analyse this claim by looking at financialisation in the European periphery, focusing on the Portuguese case. The emergence of this phenomenon is contextualised from a historical, economic and international perspective. Based on the analysis of several indicators, the paper concludes that the Portuguese economy exhibits symptoms of financialisation, and that this has not only revealed the structural weaknesses of the Portuguese economy but also played an important role in the emergence of the recent Portuguese sovereign debt crisis.
\end{abstract}

\section{KEYWORDS:}

Portugal, Financialisation, Liberalisation, Deregulation, Globalisation, and Sovereign Debt Crisis.

JEL: B50, E44, E60.

\footnotetext{
${ }^{1}$ The authors are grateful for the helpful comments and suggestions of Ana Santos, Andrew Brown, David Spencer, Nuno Teles, Slim Souissi, the participants in the first FESSUD Annual Conference (Berlin, October 2012), the participants in the Financialisation Seminar (Centro de Estudos Sociais - University of Coimbra, December 2012), the participants in the $3^{\text {rd }}$ International Conference in Economics (Universidade Portucalense - Infante D. Henrique, May 2013), the participants in $4^{\text {th }}$ Annual Conference in Political Economy (Erasmus University Rotterdam, July 2013) and the participants in Dinâmia'CET-IUL Workshop on Dinâmicas Socioeconómicas e Territoriais Contemporâneas (ISCTE-IUL, June 2015). The usual disclaimer applies.
} 


\section{INTRODUCTION}

In recent years, finance has acquired great prominence and assumed growing dominance over the economy in most developed economies (e.g. Greta R. Krippner, 2005 and 2011; Gerald Epstein, 2005; Thomas Palley, 2007; Özgür Orhangazi, 2008; and Gerald F. Davis, 2009), such that 'it is difficult to escape the impression that we live in a world of finance' (Krippner, 2005, p. 173). This process, which according to Basak Kus (2012), began in the US during the early 1980s following deregulatory reforms under the Reagan Administration, has been referred to as financialisation.

An increasingly diverse body of literature has addressed the causes, patterns and consequences of financialisation. In the wake of the Great Recession, many authors suggest it has contributed to the subprime crisis and thus to exacerbating the levels of anaemic growth, unemployment, inequality and poverty that had existed before this crisis (e.g. Palley, 2007; Richard B. Freeman, 2010; and Paul Kedrosky and Dane Stangler, 2011).

Our goal in this paper is to study financialisation in Portugal. This case study describes the financialisation process and its connection to crisis dynamics in a country that does not follow the pure neo-liberal financialisation model observed in more developed countries (to which the literature pays greater attention). Portugal belongs to a monetary union and has an intermediate development level, sharing characteristics of both developed and peripheral countries.

We find that the strong growth of the financial sector in Portugal was preceded by liberalisation and deregulation. Other features of the financialisation process that have been part of the evolution of the Portuguese economy in recent decades include the heavy indebtedness of the non-financial sector, the involvement of non-financial corporations (NFC) in financial activities, the extension of markets to new areas, banks' credit policy targeting the non-tradable goods sector, and the existence of a deep economic crisis. Initially, and until the late 1990s, financialisation implied strong economic dynamics, mainly underpinned by high credit growth. However, the economy started to lose momentum at the turn of the millennium and its structural weaknesses emerged clearly; later, this gave rise to the sovereign debt crisis. We argue that the financialisation process played an important role in creating the conditions that led to the Portuguese debt crisis.

The remainder of the paper is organised as follows. Section 2 presents a selected literature review on the concept of financialisation, its manifestations and main implications around the world. The change in the regulatory framework of the financial sector in Portugal is discussed in Section 3. Section 4 highlights the main signs of financialisation in the Portuguese economy. In Section 5, we emphasise the role of financialisation in the emergence of the Portuguese sovereign debt crisis. Finally, Section 6 concludes.

DINÂMIA'CET - IUL, Centro de Estudos sobre a Mudança Socioeconómica e o Território 


\section{FINANCIALISATION AND ITS CONSEQUENCES: A REFERENCE TO THE LITERATURE}

For many years, the financial system worldwide was subject to such strict regulations and restrictions on interest rates, products, and the volume and allocation of credit that some authors talked about financial repression (Malcolm Sawyer, 2014). However, a strong drive for the liberalisation and deregulation of the financial system began in the 1980s on the ground that financial development was thought to be crucial to higher economic growth as it had a positive effect on savings and thus investment; this view was supported by both theoretical (Ross Levine, 2005) and empirical arguments (Levine, 2005; James B. Ang, 2008; and Philip Arestis, Georgios Chortareas and Georgios Magkonis, 2015). As a result, regulations were slackened, ceilings on interest rates removed, reserve requirements lowered, directed credit programmes abolished, and international capital controls eliminated (Sawyer, 2014 and 2015).

The deregulation and liberalisation of the financial sector resulted in a vast growth of the financial system in relation to savings and investments, not only through deposits, loans and stock market valuation, but also derivatives, securitisation, and shadow banking (Epstein, 2005). This originated excessive financial deepening, casting doubts on the "finance-growth nexus" (Sawyer, 2014). Empirical studies confirm the decrease or even reverse in the relationship between financial development and economic growth (M. Ayhan Kose et al., 2006; Eswar S. Prasad, Raghuram G. Rajan, and Arvind Subranmanian, 2007; Peter L. Rousseau and Paul Wachtel, 2011; Stephen G. Cecchetti and Enisse Kharroubi, 2012; Adolfo Barajas et al., 2013; and Era Dabla-Norris and Narapong Srivisal, 2013). Excessive financial deepening and its negative impacts on the economic system has been referred to as financialisation or financedominated capitalism ${ }^{2}$. Although there is no single and generally accepted definition of financialisation (Krippner, 2004; and Fernando I. Leiva and Stanley Malinowitz, 2007), one of the broadest concepts defines it as '[...] the increasing importance of financial markets, financial motives, financial institutions, and financial elites in the operations of the economy and its governing institutions, both at the national and international level' (Epstein, 2001, p. 1).

Besides the simple quantitative growth of finance, financialisation encompasses other diverse phenomena: higher profit accumulation of financial activities and financial corporations compared with other activities and NFC, respectively (Epstein, 2005; Krippner, 2005; and Engelbert Stockhammer, 2010); "shareholder value orientation", greater use of financial products (credit, insurance, fully funded pension funds, among others) by individuals, increasing international capital mobility (Stockhammer, 2010); and financial interests dominating over economic, social, environmental and political interests (Robin Blackburn,

\footnotetext{
${ }^{2}$ These two expressions are normally used interchangeably. Henceforth, we will only refer to the concept of financialisation.
} 
2006; James R. Crotty, 2007; Ben Fine, 2010; and Alessandro Vercelli, 2013), with the encroachment of finance into the realms of everyday life (Natascha van der Zwan, 2014).

Following Fine (2011), the FESSUD (2011) discusses the following features of financialisation: development and proliferation of financial markets; deregulation of the financial system and of the economy in general; the emergence of new financial instruments, services, institutions and markets (for example, the growth of the shadow banking system and securitisation - Stockhammer, 2010); the dominance of finance over other industries in the areas of investment, production and employment; significant growth of consumption supported by the increase in household debt; the diffusion of market and financial logics in economic and social areas previously unaffected by these logics; and a culture oriented to individualism, self-interest, rationalism and market values.

More recently, the "pessimistic view" of the role of finance within the financialisation concept has gained momentum in the wake of successive international financial crises; indeed, some authors have argued that financialisation contributed to the subprime crisis in the USA in 2007 and to the Great Recession in Europe in 2008-2009 (Freeman, 2010; Stockhammer, 2010; Kedrosky and Stangler, 2011; Eckhard Hein, 2012; and Donald Tomaskovic-Devey, Ken-Hou Lin and Nathan Meyers, 2015).

In this context, many authors have drawn attention to the negative effects of financialisation, which have been summarised by FESSUD (2011) as follows. Firstly, it reduces the level and efficacy of real investment as funds are diverted to financial activities (including NFC that become increasingly involved in financial activities - Crotty, 2005; and Krippner, 2005); this results in the decoupling of the financial sector from the non-financial sector (Lukas Menkhoff and Norbert Tolksdorf, 2001) and slower economic growth. Secondly, corporations normally seek to maximise their short-term financial value, overlooking their long-run survival and other social values. Thirdly, economic and social public policies are pushed into accepting market mechanisms in all areas of economic and social life, sometimes with deleterious consequences in terms of efficiency and equity. There is a rise in income inequality due to market mechanisms, public policies, and wage stagnation. Jacob Assa (2012) and Kus (2012) state that financialisation has had negative consequences on income equality, growth and employment in OECD countries. Fourthly, growing areas of economic and social life are exposed to volatility and crises, which often characterise financial markets. In general, there is greater vulnerability to debt-inflation episodes (Palley, 2007) and financial crises (Stockhammer, 2010; Freeman, 2010; and Sawyer, 2014).

Although financialisation is more developed in the USA and UK economies (Fine, 2011; Palley, 2007; and Shaun French, Andrew Leyshon, and Thomas Wainwright, 2011), it is present in most economies, albeit with some heterogeneity in time and space (Dorothy Power, Gerald 
Epstein, and Matthew Abrena, 2003; Arjun Jayadev and Gerald Epstein, 2007; Leiva and Malinowitz, 2007; Palley, 2007; Orhangazi, 2008; Sawyer, 2013 and 2015; and Vercelli, 2013). This heterogeneity may be related with the dichotomy between "bank-based (or dominated) financial systems" and "market-based (or dominated) financial systems" (Sawyer, 2014). Nevertheless, both types of financial system support financialisation (Sawyer, 2015).

Stockhammer (2010) and Hein (2012) confirm that financialisation is not homogeneous across countries and propose classifying long-run development patterns in the financialisation era into three paths of development: the 'debt-led consumption boom'; 'domestic demand-led' development; and 'export-led mercantilist' development.

While differences are found in the financialisation of core countries, its dynamics on the periphery are even more dissimilar. Although this aspect is often neglected (Joachim Becker et al., 2010; and French et al., 2011), there are a few studies analysing the specificities of financialisation in peripheral economies. Erinc Yeldan (2000) concludes that the financialisation process has negatively impacted economic growth, unemployment and income distribution in Turkey. Leiva and Malinowitz (2007) suggest that it has worsened the real economic performance of Southern (developing) economies as well as those in the North (developed), namely implying weak growth rates and lower levels of employment due to a decline of productive investments. Similarly, Becker et al. (2010) focus on financialisation in two Latin American (Brazil and Chile) and two Eastern Europe (Serbia and Slovakia) countries, finding that this phenomenon has been extremely crisis-prone in all four cases.

In an analysis of the changes in the financial systems of Southern European economies in the last 15 years, Luigi Orsi and Stefano Solari (2010) conclude that they are "bank-based" and that the banks control credit, the stock exchange and investment in shares by acting as advisers, mediators, issuers, treasurers and investors. The authors claim that universal banks in these countries are able to decide who can invest, where to invest, and who makes a profit. They also consider that the great importance of banks is the most evident sign of financialisation in these economies as they sustain the dynamism of the economy by granting high levels of credit, especially for durable goods.

In what follows, we discuss evidence and specificities of the financialisation process in the Portuguese case by looking at the points underlined by the literature: the long-run development model, deregulation of financial markets and institutions, relevance of bank credit versus financial markets, increase in financial sector profits and assets and the emergence of new financial institutions, involvement of NFC in financial activities, expansion of market mechanisms across society and the role of public policies, and the importance of financialisation in creating crisis dynamics.

DINÂMIA'CET - IUL, Centro de Estudos sobre a Mudança Socioeconómica e o Território 


\section{THE CHANGE IN THE REGULATORY FRAMEWORK: CREATING THE CONDITIONS FOR FINANCIALISATION}

The development of the Portuguese financial system occurred later than in other EU countries, mainly due to the nationalisation of the banking system in the aftermath of the $25^{\text {th }}$ April 1974 Revolution $^{3}$ and the two agreements established with the IMF in 1977 and 1983. After the 1974 Revolution, a socialist-oriented policy was adopted and in 1974 and 1975 governments announced the nationalisation of banking activity in order to prevent capital flight and to control the development of the economy. In 1976, the irreversibility of the nationalisations and the prohibition of banking activity by private agents were enshrined in the new Portuguese Constitution.

In the early 1980s, most of the banks were State-owned as a result of the nationalisation process and only mutual and cooperative institutions (Caixas Económicas and Crédito Agrícola) and foreign banks remained beyond direct State control. By 1991, the State-owned banks accounted for nearly $75 \%$ of the assets of the banking system (Paula Antão et al, 2009), which came under the direct control of the government, and banks' activities were subject to restrictive regulations, namely on interest rates and the amount of credit. The financial system was essentially repressed, characterised by weak levels of competition, innovation and efficiency (Caixa Geral de Depósitos, 2010).

The nationalisation of banks and a socialist-oriented policy led to substantial capital flight, including foreign direct investment. This together with disruptions in production (related to labour unrest), real appreciation in the exchange rate (partially associated with real wage increases), and weak external demand contributed to difficulties in the balance of payments and the budget balance, ultimately leading to the need for external financial aid in 1977 and 1983. These two agreements also slowed the development of the financial system as they attempted to correct external imbalances by imposing measures to contain the growth of domestic demand and money supply. These measures included credit limits, administrative control of interest rates, and limitations on the number and location of branches.

In 1986, Portugal joined the European Union and started integration in the European Single Market, which required the gradual dismantling of the constraints on the financial system, particularly that of State ownership of banks and insurance companies. Even though the elimination of restraints had already begun in 1983 with banking and insurance activities again opened to national and international private corporations, a new set of liberalising measures were adopted in the late 1980s that included the progressive elimination of administrative limits on interest rates, credit growth, the number and location of bank branches, and compulsory

\footnotetext{
${ }^{3}$ This was a revolution that ended a dictatorship of almost 50 years and instituted a democracy. 
investment in national public debt (Gabriela L. Castro, 2007). The latter element was important as it allowed banks to disinvest in public debt and free resources to finance the private sector. As an alternative, the State gradually increased the sale of bonds to foreign investors (in 2008 they owned $78 \%$ of public debt), but this made it more vulnerable to capital flights, as we will see below when discussing the crisis

Consequently, a significant number of foreign banks opened activity in Portugal from the mid-1980s onwards, but they still accounted for a relatively small share of the domestic market. Concurrently, new domestic banks were created and the number of domestic and foreign banks increased considerably from the mid-1980s, with the number of branches more than doubling. Whereas Portugal had 22 banks in 1985, this had risen to 62 in 2000 (Bank of Portugal, 1997 and 2000).

In 1989, amendments to the Constitution abolished the principle of the irreversibility of nationalisations, allowing the re-privatisation of banks to begin. By the end of this process in 1996, Caixa Geral de Depósitos was the only bank that remained Stated-owned, with around $20 \%$ of the assets of the banking system, a share it still held in 2013 (Banking System Statistics from Bank of Portugal, Associação Portuguesa de Bancos and Antão et al., 2009).

The re-privatisation of banks was an important milestone in the evolution of the financial system, enhancing competition and innovation. Both banks and other public companies were reprivatised mainly through public offers to promote "popular capitalism", thus contributing to the development of the stock market. Commercial banks profited from this process by giving credit to small investors wishing to buy stocks, whereas investment banks gained by advising the government on the re-privatisation operations.

Subsequently and especially after 1994, the increased competition from foreign banks and rationalisation efforts gave rise to several waves of bank takeovers that increased market concentration. Either by mergers and acquisitions or by internal growth, the re-privatisation process boosted the formation of large financial groups, consolidating the dominance of five of these. Since 1996, these five banking groups have controlled around $80 \%$ of the banking system in terms of assets, credit, resources and profits.

The adoption and inspiration of European law contributed decisively to the liberalisation and deregulation of the Portuguese financial system: the new Organic Law of the Central Bank (1990), transposition of the Second Banking Coordination Directive to the Portuguese law (1992), and implementation of the EU Capital Adequacy Directive (1990-1993). From 1989 to 1994, the reduction in the legal requirement for reserves to the European level (2\%) also allowed banks to easily extend the credit supply at low interest rates. 
Despite the liberalisation process, no financial crisis occurred for two decades in Portugal, contrary to what happened in other OECD countries (Graciela L. Kaminsky and Carmen M. Reinhart, 1999).

In the first six years of EU membership, Portugal's GDP per capita (in purchasing power parity) rapidly converged with the EU15 average, from 54\% in 1986 to $68 \%$ in 1992 . The economic dynamism until 1992 was partially explained by the faster growth of credit, to which the liberalisation of the banking system had contributed. GDP growth was also boosted by political stability and accession to the EU (which favoured by the substantial transfer of structural funds), access to loans from the European Investment Bank and significant inflows of FDI.

From the mid-1980s and particularly after 1990, Portuguese economic policy was committed to the nominal convergence strategy that was inherent to the process of monetary integration in the EU. The Portuguese government implemented a strategy of disinflation, characterised by restrictive monetary policy, anchoring of the exchange rate to the Mark, and fiscal policies aimed at reducing the external deficit and inflation. This policy strategy, especially the high real appreciation of the currency, and the crisis of the European Monetary System (EMS) in 1992-1993, led to a recession that interrupted the catching-up process. The non-tradable goods sector was particularly affected by the exchange rate peg, because its selling prices went down to international standards; but it took some time for costs (namely wages) to follow.

However, the 1993 recession was rapidly overcome, and in the remainder of the 20th century the Portuguese economy benefited from the improved performance of the international economy and the sharp reduction in real interest rates from the mid-1990s, which rapidly increased consumption and investment. The drop in interest rates was the result of the aforementioned 'nominal convergence' (in anticipation of the EMU), the liberalisation of the banking sector, and the free movement of capital within the European single market. Banks ensured the financing of the economy, borrowing money internationally and lending it internally. Portugal had a strong economic dynamism, particularly until the late 1990s, with the country converging in real terms with Europe and maintaining the public deficit under control. This dynamism was despite Portugal having the highest exchange rate appreciation of the (future) euro area countries between 1994 and 1998, due to the maintenance of a peg to the Mark in the face of larger inflation rates than in Europe. Given the high economic growth between 1995 and 2000 (4.3\% annually) and the scenario of low interest rates, the public deficit was controlled and levels of indebtedness looked relatively sustainable and, therefore, did not seem to pose a significant risk to the economy.

DINÂMIA'CET - IUL, Centro de Estudos sobre a Mudança Socioeconómica e o Território 
The good economic performance was also the result of the positive momentum of the international economy, low oil prices, favourable exchange rate developments (with the dollar appreciating against the euro) and the rise in social expenditures and public investment in the welfare state. The expansionary fiscal policy was also visible through the high level of construction of new infrastructures (namely roads and motorways), largely thanks to the EU structural funds (Orlando Abreu, 2006).

\section{EVIDENCE OF FINANCIALISATION IN PORTUGAL}

The liberalisation, deregulation and integration in the EU of the Portuguese economy created conditions for the financial sector to grow. In this section, we will examine to what extent the Portuguese economy exhibits symptoms of financialisation by analysing the indebtedness of the private sector, the financial sector's growth, the increase in financial assets, the engagement of NFC in financial activities, the evolution of credit by sector, the broadening of market interests to other areas of the economy and the orientation of public policy towards the interest of the financial sector.

\subsection{Indebtedness of the Private Non-Financial Sector and Growth of the Financial} Sector

In the early 2000s, Portuguese households and corporations were among the most indebted of the euro area. During the 1980s, the real growth of credit (obtained from the difference between the nominal growth and the inflation rate) was very low and even negative in some years (Figure 3) as a result of slow economic growth, nominal instability and also the IMF intervention. A cycle of strong growth in credit started in 1995 and reached more than $25 \%$ per year in 1999. This growth was associated with the European integration process, which affected both the demand and supply of credit. On the demand side, the participation in the European Monetary Union increased current and expected output, lowered unemployment and led to a sharp decline in nominal and real interest rates. Initially, economic agents saw these changes as permanent, fostering a substantial rise in credit demand.

On the supply side, greater competition between banks also increased the availability, sophistication and diversification of financial products, particularly in the credit segment. The greater availability of credit was made possible by the domestic banks' easier access to international financial markets, which occurred even before the arrival of the euro due to the elimination of capital controls and a marked reduction in exchange rate risk. After Portugal joined the euro, the exchange risk virtually disappeared and the access to European financial markets became even easier. Portuguese banks could diversify their funding sources by selling government bonds from their portfolios and borrowing on the euro interbank and bond markets, 
or from the ECB, making them less dependent on deposits that were going down. Moreover, the increased use of loans' securitisation facilitated banks' financing and became an important funding source. Accordingly, securitisation companies and funds started in 2001 and grew exponentially, representing 62\% of the assets of all Other Financial Institutions in 2011.

Figure 1 - Household debt (\% of GDP)

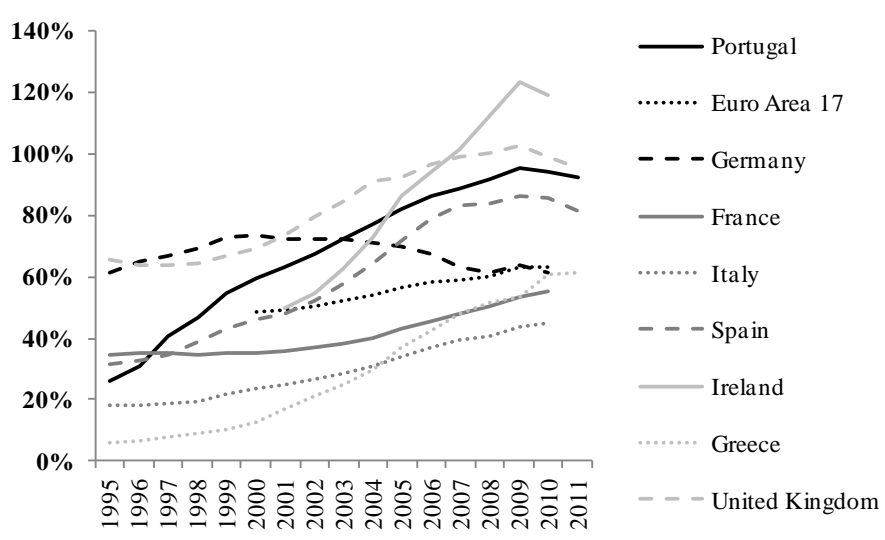

Source: Eurostat.

Figure 2 - Corporative debt ( $\%$ of GDP)

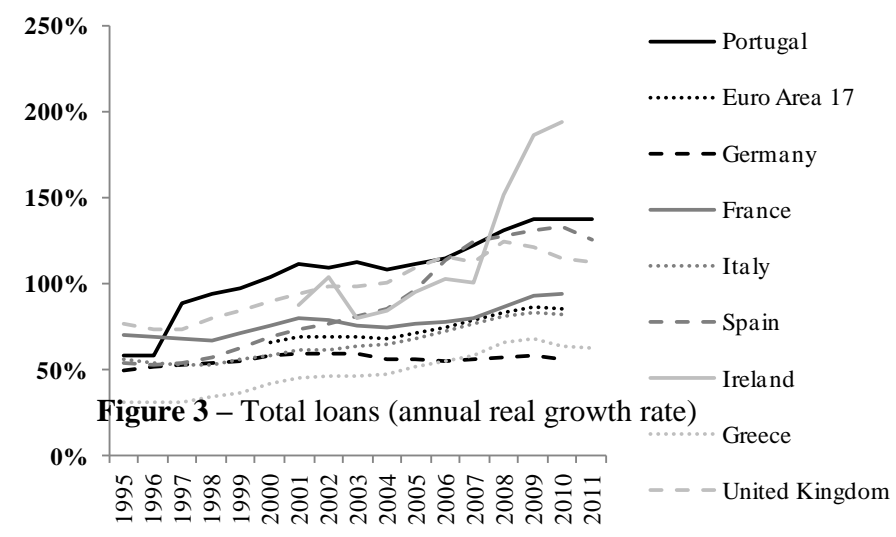

Note: Debt includes loans, securities other than shares and trade credit. Source: Eurostat 
Figure 4 - Total loans (annual real growth rate)

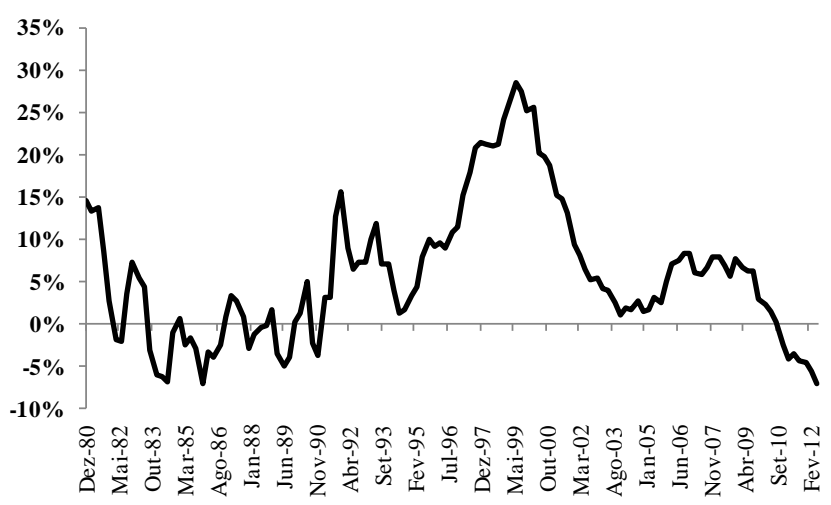

Note: Excluding financial non-monetary institutions and securitised credit.

Source: Bank of Portugal.

In this context, the easier financing allowed banks to satisfy the demand for credit, feeding the increase in household and corporate indebtedness (Figure 1 and Figure 2).

The high levels of household debt are essentially explained by the rise in mortgages from the early 1990s; house ownership boomed in Portugal, with around two-thirds of householders owning their home and $20 \%$ having a second house. House ownership was fostered by a malfunctioning rental market, the existence of subsidised mortgages by the government until September 2002, and fiscal benefits for savings designed to buy a house. Housing credit represented around $80 \%$ of total credit to households in 2011, with the remainder for consumption and other purposes. In relation to NFC, medium and long-term credit to finance investment was the segment that exhibited largest growth (Lagoa et al., 2013). The high level of NFC debt is consistent with the argument that corporations in a financialised environment are faced with pressures to raise the equity rate of return in the short run and thus resort to increasing leverage (Palley, 2007).

In sum, the strong growth of household and NFC indebtedness from 1995 is a sign of the financialisation of the Portuguese economy. Another trend observed (Stockhammer, 2010) is the increase in the shadow banking system through the growing use of securitisation.

The growth of bank credit fed the growth of the financial sector, which can be interpreted as a symptom of financialisation. From 1995 to 2011, the gross value added in the financial sector also rose considerably from 3.4\% of total gross value added in 1995 to $8.1 \%$ in 2011 (Figure 5). In 1995 the Portuguese financial sector was one of the smallest in the euro area in terms of value added (Figure 5), but its rapid growth between 1995 and 2011 meant it was higher in Portugal than the EA average. 
Figure 5 - The importance of the financial sector (\% of gross value added)

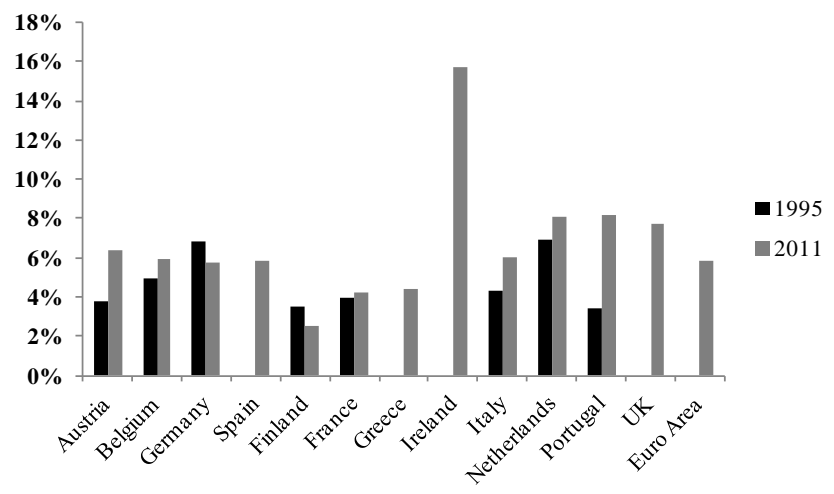

Note: The values for the euro area reflect the "changing composition".

Source: Eurostat.

The rapid growth of credit created profit opportunities for banks. Before the 2008 financial crisis, the average ROA of Portuguese banks was one of the largest in the euro area (EA). For instance, the average ROA of Portuguese banks in 2005 and 2006 was $0.93 \%$ and the unweighted average ROA of EA12 was 0.69\% (ECB, 2007).

Krippner (2005) claims that the financialisation of the economy is accompanied by a growing proportion of the economy's profits coming from financial corporations. This is confirmed by the fact that the financial sector's contribution to the surplus of the economy grew more than that of the non-financial sector from 1995: the gross operating surplus (GOS) of financial corporations in relation to the GOS of NFC increased from $14 \%$ in 1995 to $26 \%$ in 2008 , which was followed by a decline to $19 \%$ in $2011^{4}$. As GOS includes the remuneration of capital (rents, interests and profits), this evolution means that a larger share of the remuneration from capital was from the financial sector.

The growth of banking credit created two fragilities in the Portuguese financial system. Between 1997 and 2010 there was a sharp decline in banks' capital adequacy ratios, which in 2010 were among the lowest of the EA11. In 2010, the ratio of the Portuguese banking system was $10.3 \%$ compared with $13.6 \%$ in the EA11 (data from ECB Statistics on consolidated banking data). Additionally, because the growth of credit was not accompanied by that of deposits due to the decline in internal savings, the loans-to-deposits ratio rose sharply from 57\% in 1989 to $172 \%$ in 2008, making banks over-dependent on market financing (data from Bank of Portugal).

Another weakness of the banking system resulting from the recent evolution was the heavy concentration of loans in the real estate sector (households, construction and real estate corporations): the weight of these loans in total loans to the private non-financial sector went up

\footnotetext{
${ }^{4}$ Note: The values for 2010 and 2011 are forecasts. Source: INE (Annual Sector Accounts). 
from $17 \%$ in 1980 to $59 \%$ in 2008 . For the purposes of comparison, in 2008 the weight of residential real estate as a proportion of total loans (including to government and non-residents) was much larger in Portugal (32\%) than in Austria, Germany, Italy and the Netherlands (18\%) The importance of credit to the real estate sector exposes banks to a downturn in real estate prices. Notwithstanding, Portugal did not experience a boom and bust cycle in the housing market (See Section 5.2.).

Another perspective on financialisation is given by assessing financial assets in the economy and their distribution across financial sectors ${ }^{6}$. Massimo Cingolani (2013) claims that an upward trend in financial assets indicates the relative speed at which financial stocks and productive revenues develop over time and, therefore, indirectly measures the accumulation of "financial rents". In Portugal, financial assets accounted for around 719\% of GDP in 2010, which is the third highest value in EA11. On the other hand, the growth of financial assets in Portugal in 1995-2000 was quite considerable (Table 1).

Table 1 - Financial assets of the economy (\% of GDP)

\begin{tabular}{|c|c|c|c|c|c|}
\hline Country & 1995 & 2000 & 2010 & $\begin{array}{c}\text { Change } \\
\text { 1995-2000 } \\
\text { (p.p.) }\end{array}$ & $\begin{array}{c}\text { Change } \\
\text { 2000-2010 } \\
\text { (p.p.) }\end{array}$ \\
\hline Euro Area 17 & n.a & $418 \%$ & $563 \%$ & n.a. & 145 \\
\hline Belgium & $218 \%$ & $350 \%$ & $480 \%$ & 262 & 130 \\
\hline Germany & $474 \%$ & $670 \%$ & $722 \%$ & 249 & 52 \\
\hline Ireland & n.a. & n.a & $2389 \%$ & n.a. & 1284 \\
\hline Greece & $57 \%$ & $59 \%$ & $105 \%$ & 48 & 47 \\
\hline Spain & $353 \%$ & $467 \%$ & $586 \%$ & 232 & 119 \\
\hline France & $88 \%$ & $177 \%$ & $272 \%$ & 184 & 95 \\
\hline Italy & $51 \%$ & $105 \%$ & $116 \%$ & 65 & 11 \\
\hline Netherlands & $847 \%$ & $1091 \%$ & $1447 \%$ & 600 & 357 \\
\hline Austria & $384 \%$ & $469 \%$ & $633 \%$ & 249 & 165 \\
\hline Portugal & $445 \%$ & $579 \%$ & $719 \%$ & 274 & 140 \\
\hline Finland & $316 \%$ & $403 \%$ & $684 \%$ & 369 & 282 \\
\hline
\end{tabular}

Note: Consolidated figures. The change for Ireland corresponds to the period between 2001 and 2010.

Source: Eurostat (Annual Sector Accounts).

Meanwhile, like in EA17, most of the financial assets in Portugal were owned by financial corporations (including the central bank, banks and other non-monetary financial institutions). From 1995 to 2011, there was a rapid rise in financial assets held by financial corporations. In 1995, financial assets owned by households and financial corporations each represented around $175 \%$ of GDP but in 2011, financial corporations basically doubled their assets to $337 \%$ of GDP while those of households increased only to $224 \%$ of GDP. The latter increase occurred between 1995 and 1997 and then basically stagnated until 2011; this is consistent with the drop in savings and the rise in household indebtedness. Note that the growth of financial corporations'

\footnotetext{
${ }^{5}$ This is based on IMF Financial Soundness Indicators; for Italy we used 2011 data and for Germany 2007 data.

${ }^{6}$ According to Eurostat, financial assets include currency and deposits, securities and other shares, loans, shares and other equity, insurance technical reserves and other instruments receivable/payable.
} 
assets led to Portugal's convergence with the EA in terms of distribution of assets by the institutional sector (Figure 6 and Figure 7). The rapid growth of financial assets held by financial corporations may reflect a transfer of wealth from the productive sector (NFC) and households to the financial sector (Cingolani, 2013). Within the financial sector, banks were largely responsible for the growth of financial assets together with other credit institutions and credit securitisation companies and funds. Loans were the banks' fastest growing financial assets, in line with the above-mentioned rise in credit to households and NFC.

In the same period, 'the rest of the world' registered an even larger growth in the holdings of financial assets. This is a consequence of the high current account deficit, which was financed by transferring assets to foreign investors.

Figure 6 - Financial assets by institutional sector in Portugal (\% of GDP)

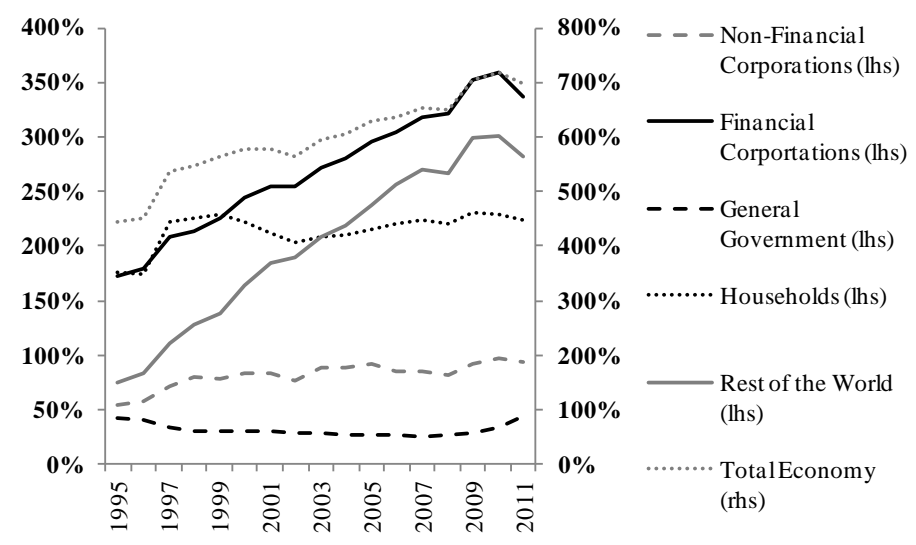

Note: Non-cumulative and consolidated figures. Households includes nonprofit institutions.

Source: Eurostat (Annual Sector Accounts).

Figure 7 - Financial assets by institutional sector in the EA 17 (\% of GDP)

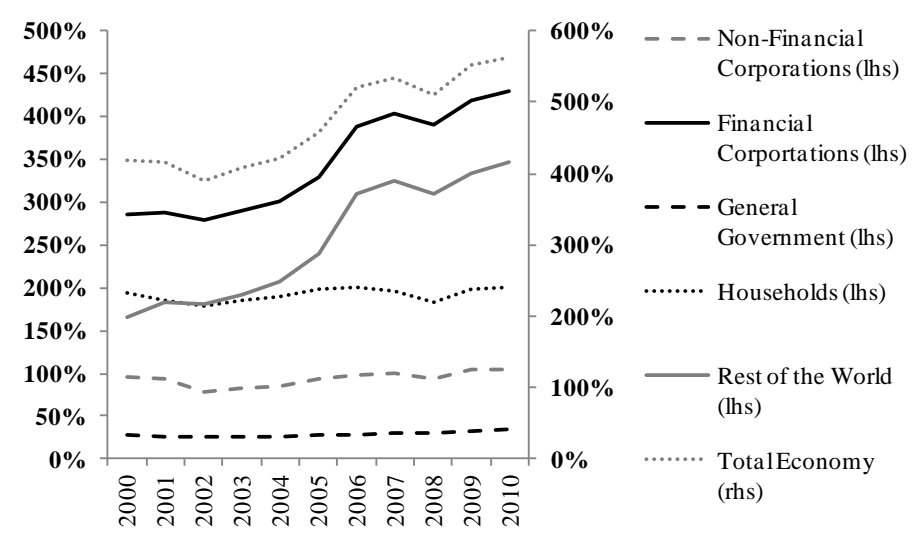

Note: Non-cumulative and consolidated figures. Households includes the nonprofit institutions.

Source: Eurostat (Annual Sector Accounts).

DINÂMIA'CET - IUL, Centro de Estudos sobre a Mudança Socioeconómica e o Território 


\subsection{Financial Engagement of Non-Financial Corporations}

It should also be noted that financial assets owned by NFC rose by 42.4 p.p. in Portugal from 1995 to 2010 (Figure 6 and Figure 7). Although the increase in the importance of these assets from 2000 was a little bigger in Portugal than in the EA17, in 2010 NFC owned slightly fewer financial assets in Portugal than in the EA17 (Figure 5 and Figure 6). As NFC should not accumulate financial assets, a large increase in the financial assets owned by those corporations indicates that they are diverting resources from productive applications to financial accumulation, distorting their main goal.

Indeed, financialisation implies that NFC become increasingly involved in financial activities and, thus, their financial profits grow more than the profits from productive activities, with a diversion of resources from real investment (Krippner, 2005). On the other hand, financial markets demand more payments from NFC, therefore reducing the capacity to finance real investment through retaining earnings. Note that the latter effect may be linked to an increase in indebtedness that increases corporations' interest payments.

Regarding the first effect, total financial receipts as a percentage of GOS had an overall positive trend in Portugal, despite some oscillation (Figure 8). The main increase was between 2003 and 2008. Looking at the components of financial receipts (interest and dividends), we observe that only dividends had a clearly positive trend from the mid-1980s.

As for the second effect, there was a decline in financial payments as a proportion of GOS until 2003 due to the fall in interest paid caused by the large cut in interest rates; but there was an upward trend in financial payments between 2004 and 2008 followed by a slightly downward trend thereafter (Figure 9). Analysing the components of financial payments, the rise in interest paid from 2006 to 2008 is explained by the increase in interest rates in the period; this clearly illustrates the risks associated with interest rate rises in a context marked by high corporate debt ratios. On the other hand, there was a moderate rise in dividends paid from the mid-1990s, followed by more rapid growth in the mid-2000s before stabilising thereafter.

Figure 8 - Receipts of NFC (\% of GOS)

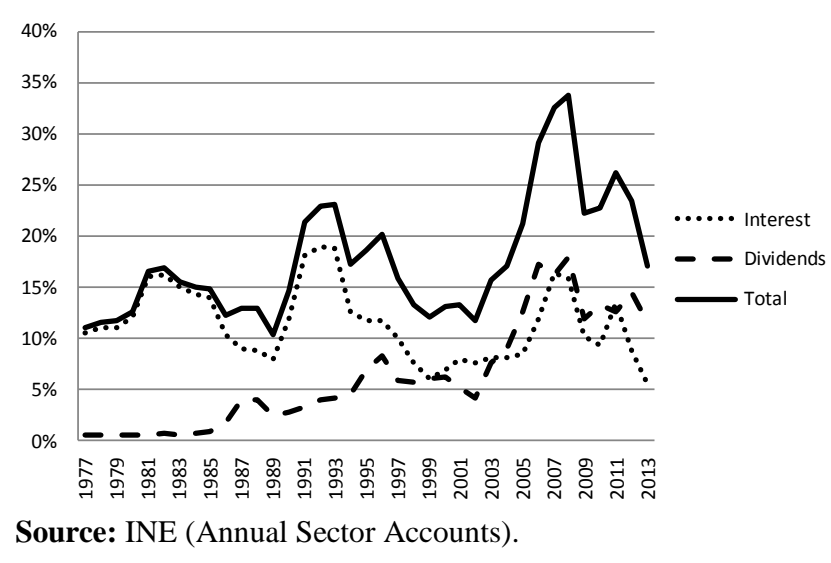


Figure 9 - Payments of NFC (\% of GOS)

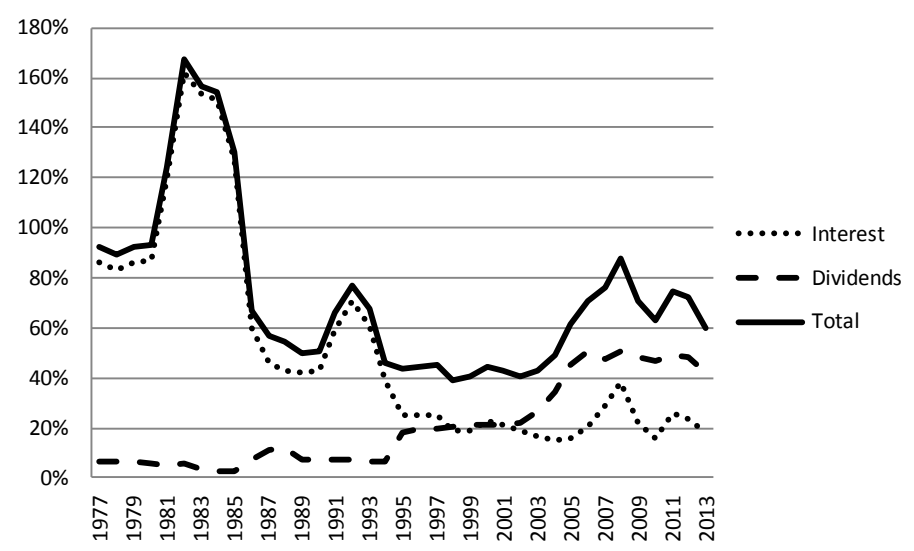

Source: INE (Annual Sector Accounts).

Importantly financial payments were, as expected, larger than financial receipts. Moreover, the rise in payments to financial actors between 2003 and 2008 and in financial receipts between 2004 and 2008 may have contributed to the observed downward trend in NFC investment in that period. High indebtedness is another factor that may have contributed to the decline in NFC investment levels from 2001.

\subsection{Sectorial Distribution of Credit across Industries}

Although banks increased credit to NFC and households, they increased the financing to nonmonetary financial institutions even more. Credit to non-monetary financial institutions in proportion of the credit to NFC jumped from $2.1 \%$ in $1980-89$ to $21.7 \%$ in $1990-99$, and rose to $24.1 \%$ in 2000-10 (Bank of Portugal data). This shows the financial system was steadily decoupling from the non-financial sector.

Another element worth underlining is that the growth of credit to NFC was quite heterogeneous across industries. An analysis of the growth of credit by industry (Table 2) in 1993-2007 clearly shows that the banking system gave more credit to construction, real estate and other non-tradable activities than to manufacturing, even though credit to manufacturing continued to grow. Moreover, a survey on investment conducted by INE (Inquérito Qualitativo de Conjuntura ao Investimento) asked corporations if they had faced credit constraints on their investments. Results show that the industries that experienced the greatest difficulties in obtaining credit between 1998 and 2007 were manufacturing, construction (especially from 2004), and transportation and storage.

Manufacturing's difficulty in obtaining credit may be explained by its slower output growth or by the fact that banks assessed it as a higher risk sector exposed to greater competitive pressures from abroad. The appreciation of the exchange rate during the 1990s to 
ensure nominal convergence with Europe, which would later allow the adoption of the euro, contributed to a decline in the tradable sector's external competition. In conjunction with the privatisation process, this created an entrepreneurial focus on the internal market (construction, real estate, support services to corporations and households, and education and health services), heavy investment in infrastructures (telecommunications, audio-visual, gas, electricity, roads, water and environment) and the consolidation of tourism (João Rodrigues and José Reis, 2012). In addition, the real estate and construction sectors offer relatively safe collateral (real estate). In a financialised economy, banks tend to allocate funds to the more profitable investments in the short run, even though they may be less desirable in the long run (Sawyer, 2015). On the other hand, this stance may also reflect the interests of banking groups in direct investments in some non-tradable sectors, such as real estate and health.

Nevertheless, the growing importance of the non-tradable goods sector in relation to that of tradable goods and the concomitant deindustrialisation of the Portuguese economy were associated with the smaller amount of credit allocated to the tradable goods sector.

Table 2 - Credit by sector (average annual growth rate)

\begin{tabular}{l|c|c|c}
\hline \multicolumn{1}{c|}{ Sector } & $\mathbf{1 9 9 3 - 1 9 9 9}$ & $\mathbf{1 9 9 9 - 2 0 0 7}$ & $\mathbf{2 0 0 7 - 2 0 1 1}$ \\
\hline Agriculture & $1.7 \%$ & $8.5 \%$ & $9.0 \%$ \\
\hline Mining & $3.0 \%$ & $2.0 \%$ & $2.8 \%$ \\
\hline Manufacturing & $\mathbf{2 . 8 \%}$ & $\mathbf{3 . 5 \%}$ & $\mathbf{3 . 6 \%}$ \\
\hline Utilities & $1.3 \%$ & $7.9 \%$ & $16.9 \%$ \\
\hline Construction & $29.5 \%$ & $14.0 \%$ & $-1.1 \%$ \\
\hline Trade & $12.4 \%$ & $4.5 \%$ & $0.1 \%$ \\
\hline Transport & $6.0 \%$ & $12.3 \%$ & $5.4 \%$ \\
\hline Hotels and Restaurants & $69.3 \%$ & $18.3 \%$ & $11.9 \%$ \\
\hline Information and Communication & $52.6 \%$ & $1.3 \%$ & $10.0 \%$ \\
\hline Holdings & $7.5 \%$ & $11.5 \%$ & $4.8 \%$ \\
\hline Real Estate & $29.5 \%$ & $16.7 \%$ & $0.9 \%$ \\
\hline Consultancy & $14.7 \%$ & $12.5 \%$ & $1.2 \%$ \\
\hline Education and Health & n.d. & $0.3 \%$ & $9.9 \%$ \\
\hline All Activities & $\mathbf{1 2 . 8 \%}$ & $\mathbf{9 . 4 \%}$ & $\mathbf{2 . 9 \%}$ \\
\hline Source: Bant & & \\
\hline
\end{tabular}

Source: Bank of Portugal.

\subsection{Broadening of Private Interests in the Economy, Taxes and Public Policy}

Another symptom of financialisation (FESSUD, 2011) is the penetration of private interests in areas previously reserved to the State. In Portugal, this was first seen due to privatisations. The large number of nationalisations that followed the 1974 Portuguese revolution was reversed through a process of privatisations from the late 1980s. As seen above, financial corporations came in the first phase of privatisations between 1989 and 1993, followed by the NFC; the process was at its peak in the late 1990s but still continues today.

More recently, private interests have entered new areas that were not open to corporations (even state owned ones), namely health provision, water provision, and construction and 
management of public infra-structures (mainly highways). For instance, the health sector has attracted the interest of private enterprises and several private hospitals have opened since 1995. The largest financial groups also own clinics and hospitals and provide medical services articulated with private health insurance. Although the public health service is the main provider of medical cares to the population, the demand for private health insurance is due to the easier access and (supposed) higher quality of medical services.

In addition to the above changes in the health sector, the public sector has also started to adopt more market-oriented mechanisms. Important examples are the establishment of publicprivate partnerships (PPP) for the construction and clinical operation of new hospitals, increased autonomy of state-owned hospitals that became public corporations, and the introduction of user fees. The aim of these changes was to boost efficiency and raise more revenues for the State in the context of a National Health Service (NHS) that is increasingly difficult to finance.

The PPP were first established in the health infrastructures sectors in 2002. In the health sector, these partnerships almost always include the construction, maintenance and management of the infrastructure. The typical PPP for hospitals is led by a private corporation responsible for obtaining finance and constructing and managing the infrastructure. Banks finance the operation and the leading corporation of the partnership may also belong to a banking group. Thus, PPP also seem to be a profitable business for banks. The State pays rent over several years to the private corporation in exchange for the construction and management of the hospital. Hospital das Descobertas, Hospital da Luz, Hospital dos Lusíadas, Hospital da Boavista, Hospital do Algarve, Hospital de Cascais, Hospital Oriental de Lisboa and Hospital Central do Algarve are some examples of PPP in the health care sector.

Nuno Teles (2015) also emphasises the concessions established through PPP in the water provision system in Portugal, particularly after 1993 with the publication of Law $n^{\circ}$ 372/93 that allowed the participation of private capital in this sector. These partnerships have guaranteed heavy investment in the sector that improved both the coverage and quality of the service provided. The financial sector benefited from this investment due to the flows of private credit into water (and indeed other utilities like electricity, gas, and waste management), the use of derivatives and issuance of bonds (mainly by Águas de Portugal) and the adoption of a pricing model that minimises the project risk (total-cost recovery that transfers financial burden from corporate providers to consumers and local authorities). The construction sector also profited from this investment with the building of huge infrastructures (many of them too large for the demand). In addition, construction corporations have direct participations in the respective concessionaries and most of the operators in these concessions are owned by stock-listed construction corporations like Mota-Engil and Somague.

DINÂMIA'CET - IUL, Centro de Estudos sobre a Mudança Socioeconómica e o Território 
Today, water services provided by PPP serve $13 \%$ of the country's population, mainly in more densely populated areas. On the other hand, municipalities have found the PPP to be costly due to the poor distribution of risks between private corporations and municipalities, namely with respect to the evolution of demand and funding costs. Most of these PPP overestimated demand, which led to an extension of the concession period and/or to an increase in tariffs.

PPP are a great incentive for Governments to construct infrastructures because they delays payment to a future date. According to Direcção-Geral do Tesouro e Finanças (2011), a very significant amount is contracted under PPP, and accounted for around 1\% of GDP a year between 2011 and 2018. Most of these contractual investments pertain to road infrastructures, followed by healthcare infrastructures, and many were characterised by a lack of transparency and accountability (João Andrade and Adelaide Duarte, 2011). In sum, PPP represent a negative pressure on the fiscal budget in the medium and long-term.

The growing role of private enterprises and PPP in the health sector has other social and economic implications, notably a potential increase in social exclusion and inequality and the deviation of good professionals from the public sector. Finally, the increasing penetration of markets in the health sector and others formerly in the State sphere may ultimately make people's values (Samuel Bowles, 1998) become more market-oriented, with greater emphasis on competition and less on solidarity and cooperation.

The government must raise more taxes if it is going to contradict the negative pressure the PPP put on fiscal budget. In fact, the financial sector contributes to society through the payment of taxes. According to the Portuguese Tax Authority, the effective tax rate on financial and insurance activities was larger than the national average in the period between 2007 and 2010. However, the national average was pushed down by social and other activities characterised by the high level of informality. When we restrict the comparison to manufacturing industry, real estate activities, construction or health activities, the tax rate paid by financial and insurance activities was 3 to 4 p.p. lower, which could reflect a certain benefit to this sector. According to the Associação Portuguesa de Bancos (2010), lower average tax rate on profit of the financial sector is related in part with the use of the Madeira Off-shore (valid up to 2011).

The State took other significant measures to boost finance and market mechanisms: liberalisation of the banking and financial markets, fiscal incentives for households buying houses and shares in privatisations, zero taxation on capital gains on the stock market until recently, and the integration of private pension funds (with future sustainability problems) in public social security. Some of these decisions, namely the latter and the use of PPP, did not emerge spontaneously from political parties' programmes but were aimed at solving immediate public finance problems. 
Portuguese financialisation is distinct from that of core countries due to the State's role as well as other significant elements: greater dependence on banks with a secondary role for capital markets - Portugal has a "bank-based" financial system in the typology of Sawyer (2014), large entry of foreign capital, an overvalued currency (in real terms), large external deficits, and a weak productive system (Becker et al., 2010). However, the financialisation process in Portugal is hybrid because, as a member of the euro zone, it also shares characteristics of advanced economies, notably easy access to the international markets at low interest rates (José Reis et al., 2013).

The weakness of financial markets in Portugal has meant that financialisation has not progressed in the pension fund industry, with many private pension funds transferred to the public domain. Moreover, the state continues to own one of the largest banks in the financial system and has used it to conduct its financial policy (Fátima Barros and Leonor Modesto, 1999; and Robert M. Fishman, 2010).

Portuguese financialisation also diverges from the neo-liberal model in that overall personal income inequality declined during the period of major growth in finance (1995-2009). The reinforcement of the social state in areas like health, social protection and education is a factor that contributed to reducing inequality.

In conclusion, Portuguese financialisation has marked particularities due to the country's participation in the euro area, the large role played by commercial banks and the limited role of financial markets, and the less neo-liberal stance of the process.

\section{THE ROLE OF FINANCIALISATION IN THE PORTUGUESE CRISIS}

\subsection{The Long-Run Development Pattern and the Turn of the Millennium: Structural Problems and the First Signs of Crisis}

Hein (2012) classifies the long-run development patterns in the financialisation era into three types of development path: the 'debt-led consumption boom'; 'domestic demand-led' development; and 'export-led mercantilist' development. We argue that Portuguese development is best characterised by the debt-led consumption boom type - rather like Ireland, Greece or Spain -, where consumption ${ }^{7}$ is the demand component that most contributes to GDP growth and there is a steep decline in the net lending position of households ${ }^{8,9}$. This model is characterised by a period of strong economic growth fuelled by credit and, therefore, with increasing levels of indebtedness. The growth of credit is supported by large capital inflows and

\footnotetext{
${ }^{7}$ Household debt in Portugal is used largely to finance house purchases and not current consumption.

${ }^{8}$ Nacho Alvarez (2012) identifies also a consumption-driven growth model for the USA and Iceland.

${ }^{9}$ We could also name the Portuguese model debt-led domestic demand boom because in 1995-2000 there was a boom in private investment together with the explosion in private consumption.
} 
causes significant current account deficits. The growth of credit in other countries was accompanied by the emergence of a real estate bubble, but this was not the case in Portugal.

In line with the model's predictions, Portugal had strong economic dynamism, particularly until the late 1990s. Portugal is quite different from Spain, Greece and Ireland in that economic growth lost momentum at an earlier stage, namely in 2000, when the Portuguese economy faced structural problems that blocked its growth potential. Andrade and Duarte (2011) and Mamede (2012) note that the most relevant constraints to development were (and still are today) the low levels of education in the labour force (aggravated by underinvestment in public education during the dictatorship), the profile of economic specialisation (which is still dominated by industries with low value-added, low levels of technology and low wages that are highly exposed to competition from Eastern European and emerging economies) and its peripheral location in relation to the main European and world markets (entailing relevant cost disadvantages). Despite a significant effort to improve all these blockages through private and public investment, there was still a large distance from advanced Europe in 2000.

To add to those limitations, in the early 2000s the economy was also up against the consequences of growing competition from emerging Asian economies (in part due to agreements reached by the EU in the World Trade Organisation and other forums), which had a substantial impact on a number of traditional industries that employed a significant proportion of the manufacturing work force (namely, textiles, wearing apparel, footwear, wood and paper, metal products and non-metallic mineral). Moreover, many multinational corporations (especially in the automotive and related industries) shifted their productive capacity to some of the new member states after the enlargement of the EU to the Eastern European countries in 2004 to take advantage of their lower wages, higher educational levels, and geographical proximity to the main European markets.

An additional problem was that the increase in aggregate demand in the preceding years raised the labour cost, reducing external competitiveness and originating a loss of market share in foreign markets. This is a kind of "Dutch disease", whereby the Government policy of real exchange rate appreciation and lower interest rates together with EU structural funds induced a loss of external competitiveness (Andrade and Duarte, 2011; and Luís C. Cunha, 2008); however, the following factors also played a key role: the appreciation of the euro (namely in relation to the countries affected by the Asian crisis - Abreu, 2006) and Portugal's lack of preparation for the knowledge-based economy.

The loss of market position in foreign markets and sharp increase in aggregate demand from 1995 implied large successive current account deficits; this caused high foreign indebtedness that, in turn, increased interest payments to the exterior and further augmented the current account deficit. It should be noted that the energy deficit and the persistent fall in 
emigrants' remittances also contributed to the increase in the current account deficit (Rodrigues and Reis, 2012). From another perspective, current account deficits accrued from a lack of savings to support investment (Matthew Higgins and Thomas Klitgaard, 2011). The reduction in interest rates led to consumption in excess of disposable income, leading to a fall in savings. Although investment felt slightly, it remained at high levels, so that domestic saving was not enough to finance domestic investment and thus foreign indebtedness rose. In addition, investment focused on non-tradable goods (namely construction and real estate) that do not contribute to the improvement of the current account and have a slow growth of productivity. Indeed, the overall marginal efficiency of investment has declined since $1986^{10}$ and the average efficiency of capital between 1999 and 2012 after the introduction of the euro fell below the EA average: 0.02 and 0.07 , respectively.

The Portuguese economy also lost momentum at the turn of the millennium due to tighter ECB monetary policy following what appeared to be signs of overheating in the EA. Given the high level of private sector indebtedness, this had a significant negative impact on Portuguese domestic demand; it clearly shows that financialisation has made the Portuguese economy more vulnerable to interest rate shocks.

Together with the more restrictive monetary policy, the bursting of the 'dot.com bubble' (from March 2000 through 2001) triggered the first international economic crisis of the new millennium and was largely accountable for the Portuguese recession of 2003 and the increase in the Portuguese public deficit to $4.3 \%$ of GDP in 2001; this made Portugal the first country in the EA to break the Stability and Growth Pact's (SGP) 3\% limit. Before 2001, the Government followed a pro-cyclical fiscal policy that left no room for manoeuvre for an expansionary policy when the recession appeared (Abreu, 2006). In the following years, the Portuguese authorities had to comply with SGP rules, following pro-cyclical and recessionary fiscal policies.

In this context, the growth model based on the non-tradable goods sector and internal demand reached its limit, and in 2003 a period of dismal economic growth began and a decadelong divergence in relation to Europe. With lower economic growth, debt ratios of households and corporations continued to rise considerably; these were increasingly translated into lower private consumption and investment and, consequently, even lower economic growth, rising unemployment rates and public debt ratios (which surpassed the EA average for the first time in 2006, reaching $63.9 \%$ of GDP). Thus, the first negative consequences deriving from the increasing financialisation of the Portuguese economy became evident, particularly in relation to the levels of indebtedness of economic agents.

\footnotetext{
${ }^{10}$ The marginal efficiency of capital is calculated as the change in GDP at constant market prices of year T per unit of gross fixed capital formation at constant market prices of year T-5 (AMECO).
} 
Portugal's participation in the European Union and notably in the euro area was crucial to explain the high level of indebtedness, because not only had an impact on the liberalisation of the financial and banking markets, but also resulted in the country receiving large amounts of external financing at low interest rates, due to the elimination of the exchange rate risk premium. If Portugal had not been in the euro area, it would have been impossible to sustain a large external deficit for so long without an increase in interest rates, and ultimately credit growth would have been smaller. Other peripheral financialised economies outside the euro area have higher interest rates (Becker et al., 2010). On the negative side, the participation of Portugal in the European Exchange Rate Mechanism and in the euro implied a real appreciation of the currency that penalised the non-tradable sector. Moreover, the participation in the euro created in itself a positive shock to aggregate demand; it removed the monetary instruments (interest rate and exchange rate) and limited the use of fiscal policy to deal with the economic shocks in the 2000s, while making the financing of the State completely dependent on the financial markets (without a central bank to act as lender of last resort).

Indeed, the joining of Portugal to the euro area implied a reduction of interest rates that boosted private consumption and investment, overheated the economy, created inflation, and reduced external competitiveness. Without the possibility of devaluating the currency, this contributed to the reduction of economic growth.

The malfunctioning of the euro area, identified in the literature by many authors (see for instance Baldwin and Giavazzi, 2015) is also to blame for the Portuguese crisis. Firstly, despite large differences in economic structures, in the euro area there is a lack of adjustment mechanisms to asymmetric demand shocks. Besides the insufficiency of wage adjustments and mobility of workers as effective adjustment tools, there are strong limitations to national budgetary policies arising from the Growth and Stability Pact and the Budgetary Treaty, and there is in addition insufficiency of transferences from the EU budget to countries in economic difficulty. The non-coordination of national economic policies was also a key point, because some countries (notably Germany) followed a strict wage policy with large current accounts surpluses, which were linked to large current account deficits in the Southern countries. Finally, the inability of the ECB to act as a lender of last resort to Governments, created multiple equilibria determined by markets' expectations, making the euro area sovereign bonds' markets vulnerable to speculative attacks. And the sovereign debt crisis showed that the euro area did not have institutions and mechanisms able to financially support the countries facing liquidity crises, which rapidly transformed in to solvability crises (De Grauwe, 2011). 


\subsection{The Subprime Crisis}

At the end of 2007 and in 2008, the international economy was affected by the collapse of the subprime credit segment in the USA. As a result, some segments of interbank money markets, particularly for longer maturities, dried up, leading to a liquidity shortage with direct effects in the reduction in banking credit and the rise in interest rates on loans. The credit restraint hit confidence, consumption and business investment, namely the consumption of durable goods and purchase of houses, causing the steepest downturn on record since the Great Depression. The strong trade connections between countries also facilitated the rapid cross-country propagation of the economic crisis.

Neither Europe nor Portugal had a subprime market like that of the USA (Bank of Portugal, 2008) and there are therefore marked differences between the mortgage market in the USA and Portugal (Bank of Portugal, 2008). First of all, the percentage of households with mortgages is substantially smaller in Portugal (30\%) than the USA (45\%), or indeed in other European countries like the Netherlands (38\%) and the UK (40\%). On the other hand, Portugal has one of the lowest ratios of credit instalments-to-income in the EA (around 14\%), and has also exhibited a low loan-to-value ratio. Finally, households with mortgages are relatively well off (Ana Santos, Nuno Serra and Nuno Teles, 2015).

On the other hand, Portuguese house prices rose more modestly than in other countries like the UK, Ireland or Spain. It should be noted that nominal Portuguese house prices increased much less than the euro area average between 2000 and 2011: 21.1\% and 54.2\%, respectively. The Bank of Portugal (2010) stresses that house prices in Portugal have evolved in line with the fundamentals. From the mid-1990s, the increase in the supply of new houses avoided a surge in house prices and a housing price bubble, and a continuous stream of banking credit for households to buy houses maintained demand and sustained prices (Reis et al., 2013).

In addition, Portuguese banks had no "toxic financial products" in their portfolios, so the main difficulty arising from the subprime crisis was that of obtaining funding in financial markets. The high level of mistrust between banks caused the risk premium between Euribor and T-Bills to jump and the amount of funds traded fell sharply. Nevertheless, the funding difficulties of Portuguese banks were overcome due to the State guarantee to new issues of securitised debt by banks, as well as by the large liquidity offered by the ECB at low interest rates. Additionally, the increase in the demand for deposits by households at a time of high risk aversion and aggressive marketing strategies to attract deposits helped mitigate the funding difficulties of Portuguese banks. More generally, the downward trend in the savings rate at the start of the century was reversed.

The increase in the perceived credit risk led Portuguese banks to increase credit spreads, which implied a considerable deceleration of credit (see Figure 3) and domestic demand. The 
difficulty in obtaining credit has increased more quickly than overall limitations to investment from 2007, becoming the third most important limiting factor to investment in 2011 (INE, Inquérito Qualitativo de Conjuntura ao Investimento).

\subsection{The Sovereign Debt Crisis}

In this context and like most international economies, the Portuguese economy slipped into a recession in the third quarter of 2008 that was unprecedented in the post-war period. However, the Portuguese economy was initially less affected by the subprime crisis than the EA, with GDP falling less than in the EA in 2009. That was due to the government's anti-cyclical response (largely explained by automatic fiscal stabilisers) in 2009 (Bank of Portugal, 2011: 96) following the European guidelines. The support to the financial sector was also responsible for the increase in public spending, as in the EU. ${ }^{11}$ Consequently, there was a sharp rise in the fiscal deficit in 2009, exceeding that of other EA countries, so that in 2010 it had one of the worst fiscal deficits in the EA (10.2\% for Portugal and 6.4\% for EA12) and thus public debt went from close to the EA average in 2009 to considerably over that average in 2010 and 2011.

The financialisation process made the country vulnerable in many ways. Firstly, the growth of private indebtedness funded by foreign debt made it difficult to finance the country at a time of increasing risk aversion in the financial markets. Secondly, the growth of debt was not accompanied by significant economic growth. The debt-led domestic demand model of growth was not sustainable because it depended on a continuing rise in debt. There had been signs of agents' difficulties in coping with the levels of credit since 2008 as non-performing loans rose considerably, especially in credit to consumption and some industries. Moreover, the investment made did not lead to increased productivity, as it went to the non-tradable goods sector dependent on domestic demand and with less potential for productivity growth. Thirdly, indebted households and corporations became more exposed to increases in interest rates and to fluctuations in the business cycle. Finally, but of less importance, the use of PPP facilitated the increase in public investment that would only be paid for in the future.

The high levels of debt in the private and public sectors, which became high levels of external indebtedness for the economy, triggered doubts among international investors about the capacity of households, corporations and the State to pay their debts in a scenario of low structural economic growth. From 2007 onwards, in a global context of greater risk aversion and aggravated by the Greek situation, the increased perception of the risk of Portuguese public debt

\footnotetext{
${ }^{11}$ According to UNCTAD (2011), the measures to support the financial sector in the EU27 (including recapitalisation schemes, guarantees, asset relief interventions and liquidity measures) accounted five times the overall amount of State aid to other sectors.
}

DINÂMIA'CET - IUL, Centro de Estudos sobre a Mudança Socioeconómica e o Território ISCTE-IUL - Av. das Forças Armadas, 1649-026 Lisboa, PORTUGAL

Tel. 210464031 - Extensão 293100 E-mail: dinamia@iscte.pt http://dinamiacet.iscte-iul.pt/ 
meant that the interest rates paid by the Portuguese government and, consequently, banks began soaring and thus made the financing of the State and banks more costly.

The continuous deterioration of the Portuguese situation, especially on the bond market, was also connected to the rating agencies' downgrading of the Portuguese sovereign debt in 2010, followed inevitably by the reduction in the credit rating of most Portuguese companies. In a few months, the Portuguese private and public debt fell to junk status, worsening funding conditions in the international financial markets.

As a result, the Portuguese government requested financial assistance from the EU, the IMF and the ECB (the so-called Troika) in April 2011. The financial assistance covered the period between 2011 and 2014 with total funding of 78 billion euros. At the end of the programme, the Portuguese State was able to obtain financing in the debt market at sustainable interest rates. In exchange for financing, Portugal agreed to a set of structural reforms to increase potential output growth, the deleveraging of the financial system and a trajectory of fiscal consolidation.

\section{CONCLUSION}

This paper aimed to analyse the financialisation of the Portuguese economy over the last three decades. Although the growth of the financial sector came later than other EU countries, the steady integration into the EU after 1986 led to the liberalisation and deregulation of the financial system, with the formation of large banking groups and conditions that allowed the development of financialisation.

Our first major finding is significant evidence of financialisation in Portugal, namely in the deregulation and liberalisation of the financial sector, increasing importance of the financial sector and financial assets to GDP, emergence of new financial institutions, heavy indebtedness of the private sector, larger credit growth directed towards the non-tradable goods sector, involvement of NFC in financial activities, decrease in the efficiency of real investment, privatisation of State corporations, and finally increase in financial interests in the health-care and water provision sectors and in the construction and management of public infra-structures. However, we identified marked particularities in the Portuguese financialisation and an important contribution of the country's euro area membership for its financialisation process.

There was strong momentum in the Portuguese economy from 1995 to the turn of the millennium, particularly boosted by the greater availability of credit at lower interest rates, resulting in very robust domestic demand in accordance with a consumption-driven growth model. Nevertheless, Portuguese economic growth started to slow down in the early 2000s due to the emergence of structural weaknesses paved in the previous two decades. Portugal was then confronted with the Great Recession, the increase in budget deficit and the greater risk aversion 
of international bond investors, in addition to the vulnerabilities created by the financialisation process (high levels of private and public debt financed externally and slow structural growth); the resulting rapid decline in funding conditions forced the Portuguese government to request financial assistance from IMF, ECB and EU. In sum, our second major finding is that the Portuguese case shows that financialisation makes the economy more prone to financial crisis.

The troika imposed a demanding austerity programme with the aim of achieving "internal devaluation", increasing the potential output growth, ensuring the deleveraging of the financial system and a trajectory of fiscal consolidation. This programme triggered a strong deterioration in the Portuguese economy so that fiscal consolidation was difficult to achieve; as a result, some claim that Portugal should exit from the euro area so that it can use currency devaluation instead of wage devaluation. Economic recovery seems difficult to achieve without resolving the structural supply weaknesses in the Portuguese economy and expansionary policies at the European level to mitigate the absence of effective mechanisms that address asymmetric developments across economies.

\section{REFERENCES}

ABREU, Orlando. 2006. "Portugal's boom and bust: lessons from euro newcomers." ECFIN Country Focus, 3(16): 1-6.

ALVAREZ, Nacho. 2012. "The Financialization of the Spanish Economy: Debt, Crisis and Social Cuts." International Viewpoint. November 26.

ANDRADE, João. S. and Adelaide Duarte. 2011. "The Fundamentals of the Portuguese Crisis." Panoeconomicus, 58(2): 195-218.

ANG, JAMES B. 2008. "A Survey of Recent Developments in the Literature of Finance and Growth." Journal of Economic Surveys, 22(3): 536-576.

ANTÃO, Paula, Miguel Boucinha, Luísa Farinha, Ana Lacerda, Ana C. Leal, and Nuno Ribeiro. 2009. "Integração financeira, estruturas financeiras e as decisões das famílias e das empresas" In A Economia Portuguesa no Contexto da Integração Económica, Financeira e Monetária, ed. Banco de Portugal 423-561. Lisboa: Departamento de Estudos Económicos.

ARESTIS, Philip, Georgios Chortareas and Georgios Magkonis. 2015. "The Financial Development and Growth Nexus: A Meta-Analysis.” Journal of Economic Surveys, 29(3): 549565. 
ASSA, Jacob. 2012. "Financialisation and its Consequences: the OECD Experience." Finance Research, 1(1): 35-39.

ASSOCIAÇÃO PORTUGUESA DE BANCOS, ed. 2010. Boletim Informativo. Lisboa.

BALDWIN. R. and F. Giavazzi (ed.). 2015. The Eurozone Crisis: A Consensus View of the Causes and a Few Possible Solutions, CEPR Press, London, UK.

BANK OF PORTUGAL, ed. 1997. Annual Report. Lisbon: Economics and Research Department and Control and Accounting Department.

BANK OF PORTUGAL, ed. 2000. Annual Report. Lisbon: Economics and Research Department and Control and Accounting Department.

BANK OF PORTUGAL, ed. 2008. Financial Stability Report. Lisbon: Economics and Research Department.

BANK OF PORTUGAL, 2010. Annual Report. Lisbon: Economics and Research Department and Control and Accounting Department.

BANK OF PORTUGAL, 2011. Annual Report. Lisbon: Economics and Research Department and Control and Accounting Department.

BARAJAS, Adolfo, Thorsten Beck, Era Dabla-Norris, and Seyed Reza Yousefi. 2013. "Too Cold, Too Hot, or Just Right? Assessing Financial Development Across the Globe.” IMF Working Paper $N^{\circ} 13 / 81$.

BARROS, Fátima and Leonor Modesto. 1999. "Portuguese banking sector: a mixed oligopoly?" International Journal of Industrial Organization, 17(6): 869-886.

BECKER, Joachim, Johannes Jäger, Bernhard Leubolt, and Rudy Weissenbacher. 2010. "Peripheral Financialisation and Vulnerability to Crisis: A Regulationist Perspective." Competition and Change, 14(3-4): 225-247.

BLACKBURN, Robin. 2006. "Finance and The Fourth Dimension." New Left Review, 39: 3970.

BOWLES, Samuel. 1998. "Endogenous Preferences: The Cultural Consequences of Markets and other Economic Institutions.” Journal of Economic Literature, 36(2): 75-111.

DINÂMIA'CET - IUL, Centro de Estudos sobre a Mudança Socioeconómica e o Território 
CAIXA GERAL DE DEPÓSITOS. 2010. "Desenvolvimento da Economia Portuguesa." Relatório CGD.

CASTRO, Gabriela. L. 2007. "The Wealth Effect on Consumption in the Portuguese Economy" In Economic Bulletin - Winter 2007, ed. Bank of Portugal, 37-55. Lisbon: Economics and Research Department.

CECCHETTI, Stephen G. and Enisse Kharroubi. 2012. "Reassessing the impact of finance on growth.” BIS Working Papers No 381.

CINGOLANI, Massimo. 2013. "Finance Capitalism: A Look at the European Financial Accounts." Panoeconomicus, 3: 249-290.

CROTTY, James R. 2005. “The Neoliberal Paradox: The Impact of Destructive Product Market Competition and Impatient Finance on Nonfinancial Corporations in the Neoliberal Era" In Financialisation and the World Economy, ed. Gerald A. Epstein, 77-110. Cheltenham: Edward Elgar Publishing Limited.

CROTTY, James R. 2007. "If Financial Market Competition is so Intense, Why are Financial Firms Profits so High? Reflections on the Current 'Golden Age' of Finance.” Political Economy Research Institute Working Paper $\mathrm{N}^{\mathrm{o}} 134$.

CUNHA, Luís. C. 2008. “Is the Dutch Disease Pandemic in the South?” In Challenges Ahead for the Portuguese Economy, ed. Francesco Franco, 147-158. Lisboa: Imprensa de Ciências Sociais.

DABLA-NORRIS, Era and Narapong Srivisal. 2013. "Revisiting the Link Between Finance and Macroeconomic Volatility.” IMF Working Paper No 13/29.

DAVIS, Gerald F. 2009. Managed by the Markets: How Finance Reshaped America. Oxford: Oxford University Press.

DE GRAUWE, P. 2011. "Only a More Active ECB Can Solve the Euro", Centre for European Policy Studies Policy Briefs, No. 250, August.

DIRECÇÃO-GERAL DO TESOURO E DAS FINANÇAS. 2011. "Parcerias Público-Privadas e Concessões - Relatório de 2011".

ECB, ed. 2007. EU Banking Sector Stability, Frankfurt am Main. 
$\overline{\text { EPSTEIN, Gerald A. 2001. "Financialisation, Rentier Interests and Central Bank Policy.”, }}$ http://www.peri.umass.edu/fileadmin/pdf/financial/fin_Epstein.pdf.

EPSTEIN, Gerald A. 2005. Financialisation and the World Economy. Cheltenham: Edward Elgar Publishing Limited.

FESSUD. 2011. "Description of Work." Grant Agreement N 266800 for Collaborative Project Under Framework Programme 7 of the European Union. http://www.fessud.eu/wpcontent/uploads/2012/09/42bbf5b22295c615402a9bf9562ab4a4.pdf.

FINE, Ben. 2010. “Locating Financialisation.” Historical Materialism, 18(2): 97-116.

FINE, Ben. 2011. "Financialisation on the Rebound.” http://eprints.soas.ac.uk/12102/1/dumenil.pdf.

FISHMAN, Robert M. 2010. "Rethink the Iberian Transformations: How Democratization Scenarios Shaped Labor Market Outcomes." Studies in Comparative International Development, 45(3): 281-310.

FREEMAN, Richard B. 2010. "It's financialisation!” International Labour Review, 149(2): 163-183.

FRENCH, Shaun, Andrew Leyshon, and Thomas Wainwright. 2011. "Financializing space, spacing financialization.” Progress in Human Geography, 35(6): 798-819.

HEIN, Eckhard. 2012. The Macroeconomics of Finance-dominated Capitalism - and its Crisis. Cheltenham: Edward Elgar Publishing Limited.

HIGGINS, Matthew and Thomas Klitgaard. 2011. "Saving Imbalances and the Euro Area Sovereign Debt Crisis." Current Issues in Economics and Finance, 17(5): 1-11.

JAYADEV, Arjun and Gerald Epstein. 2007. "The Correlates of Rentier Returns in OECD Countries.” Political Economy Research Institute Working Paper No 123.

KAMINSKY, Graciela L. and Carmen M. Reinhart. 1999. "The Twin Crises: The Causes of Banking and Balance-of-Payments Problems." The American Economic Review, 89(3): 473500 .

DINÂMIA'CET - IUL, Centro de Estudos sobre a Mudança Socioeconómica e o Território 
KEDROSKY, Paul and Dane Stangler. 2011. "Financialization and Its Entrepreneurial Consequences.” Kauffman Foundations Research Series: Firm Formation and Economic Growth.

KOSE, M. Ayhan, Eswar Prasad, Kenneth S. Rogoff, and Shang-Jin Wei. 2006. "Financial Globalization: A Reappraisal.” NBER Working Paper No 12484.

KRIPPNER, Greta R. 2004. “What is Financialization?” Unpublished.

KRIPPNER, Greta. R. 2005. "The Financialisation of the American Economy." SocioEconomic Review, 3(2): 173-208.

KRIPPNER, Greta. R. 2011. Capitalizing on Crisis: The Political Origins of the Rise of Finance. Cambridge: Harvard University Press.

KUS, Basak. 2012. "Financialisation and Income Inequality in OECD Nations: 19952007." The Economic and Social Review, 43(4): 477-495.

LAGOA, S., Leão, E., Mamede, R., Barradas, R. (2013), Report of the Financial System in Portugal, Studies in Financial Systems No 9, FESSUD, Leeds.

LEIVA, Ferando I. and Stanley Malinowitz. 2007. "Financialization in the Americas: Evidence and Consequences. http://www.fleiva.files.wordpress.com/2009/10/lasa-financialization-in-theamericas.pdf.

LEVINE, Ross. 2005. "Finance and Growth: Theory and Evidence" In Handbook of Economic Growth, ed. Phillippe Aghion and Steven N. Durlauf, 865-934. Elsevier.

MAMEDE, Ricardo. P. 2012. "Causes, consequences and ways out of the crisis: a perspective from EU's periphery." Green European Journal, 1: 30-46.

MENKHOFF, Lukas and Norbert Tolksdorf. 2001. Financial Market Drift: Decoupling of the Financial Sector from the Real Economy. Heidelberg: Springer.

ORHANGAZI, Özgür. 2008. Financialization and the US Economy. Cheltenham: Edward Elgar Publishing Limited.

ORSI, Luigi and Stefano Solari. 2010. "Financialisation in Southern European Economies." Institutional Change and Trajectories of Socio-Economic Models Working Paper $\mathrm{N}^{\mathrm{o}} 2$. 
PALLEY, Thomas I. 2007. "Financialisation: What it is and Why it Matters." Political Economy Research Institute Working Paper No 153.

PRASAD, Eswar S., Raghuram G. Rajan, and Arvind Subranmanian. 2007. "Foreign Capital and Economic Growth.” National Bureau of Economic Research Working Paper No 13619.

POWER, Dorothy, Gerald Epstein, and Matthew Abrena. 2003. "Trends in the Rentier Income Share in OECD Countries, 2960-2000.”, Political Economy Research Institute Working Paper $\mathrm{N}^{\mathrm{o}} 58 \mathrm{a}$.

REIS, José, João Rodrigues, Ana Santos, and Nuno Teles. 2013. "Compreender a Crise: A economia portuguesa num quadro europeu desfavorável" In Anatomia da Crise: Identificar os problemas para construir alternativas, ed. Observatorio sobre Crise e Alternativas. Coimbra: Centro de Estudos Sociais.

RODRIGUES, João and José Reis. 2012. "The Asymmetries of European Integration and the Crisis of Capitalism in Portugal." Competition and Change, 16(3): 188-205.

ROUSSEAU, Peter L. and Paul Wachtel. 2011. "What is Happening to the Impact of Financial Deepening on Economic Growth.” Economic Inquiry, 49(1): 276-288.

SANTOS, Ana, Nuno Serra, and Nuno Teles. 2015. "Finance and Housing Provision in Portugal.” FESSUD Working Paper Series $N^{\circ} 79$.

SAWYER, Malcolm. 2013. "What Is Financialization?" International Journal of Political Economy, 42(4): 5-18.

SAWYER, Malcolm. 2014. "Financial development, financialisation and economic growth." FESSUD Working Paper Series No 21.

SAWYER, Malcolm. 2015. "Financialisation, financial structures, economic performance and employment.” FESSUD Working Paper Series No 93.

STOCKHAMMER, Engelbert. 2010. "Financialization and the Global Economy." Political Economy Research Institute Working Paper No 240.

TELES, Nuno. 2015. "Financialisation and neoliberalism: The case of water provision in Portugal.” FESSUD Working Paper Series No 102.

DINÂMIA'CET - IUL, Centro de Estudos sobre a Mudança Socioeconómica e o Território 
TOMASKOVIC-DEVEY, Donald, Ken-Hou Lin and Nathan Meyers. 2015. "Did financialization reduce economic growth?" Socio-Economic Review, 13(3): 525-548.

UNCTAD, ed. 2011. Trade and Development Report. Geneva: United Nations.

VAN DER ZWAN, Natascha. 2014. "Making sense of financialisation." Socio-Economic Review, 12(1): 99-129.

VERCELLI, Alessandro. 2013. "Financialization in a Long-Run Perspective." International Journal of Political Economy, 42(4): 19-46.

YELDAN, Erinc. 2000. "The Impact of Financial Liberalization and the Rise of Financial Rents on Income Inequality: The Case of Turkey." UNU World Institute for Development Economics Research Working Paper Nº 206. 